\title{
InfoNorth
}

\section{Voices from the Margins: The Muskekowuck Athinuwick/Cree People of Northern Ontario and the Management of Wabusk/Polar Bear}

\author{
by R. Harvey Lemelin, David Peerla and Brian Walmark
}

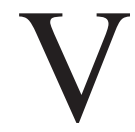

ARIOUS STUDIES ON POLAR BEARS (Wabusk in Cree) indicate that the health and distribution of this animal and its habitat (i.e., dens, staging areas) are being affected by climate change (Scott et al., 2002; Obbard et al., 2006, 2007). Of special concern to the Muskekowuck Athinuwick/Cree People of northern Ontario are the Western Hudson Bay and the Southern Hudson Bay polar bear populations (the two located in Winipekw, or Hudson and James bays), which the Cree comanage along with other stakeholders (i.e., Manitoba, Nunavut, Quebec, and other indigenous people with aboriginal and treaty rights). The co-management discussions among indigenous people with aboriginal and treaty rights and other stakeholders are complicated by proposed legislation that would change the polar bear's status in the United States and Canada (Lunn et al., 2006); by Inuit criticism of these proposed changes, which will affect their traditional practices (Freeman and Wenzel, 2006); and by the absence of the Muskekowuck Athinuwick/Cree People of northern Ontario from these discussions.

This essay has two aims: to advocate Cree engagement in polar bear management and to remind resource managers, environmental non-governmental organizations, researchers, and academics that the Cree are a sovereign people with aboriginal and treaty rights that are affirmed and recognized in the Canadian Constitution. Although we do not claim to be objective, we do recognize-as Latour (1999) did-that all ways of knowing are socially constructed and influenced. We thus situate our subjectivity by stating that our perspective is not supported by any oil company, hunting proponent, or nonprofit environmental group. Two of the authors work with First Nation organizations, while the third is Métis. What we are attempting to do in this article is to ensure that all voices involved with polar bear management are heard. So far, the voice of the Muskekowuck Athinuwick/Cree People of northern Ontario, a recognized stakeholder in polar bear management, has been virtually silenced throughout polar bear debates. Reasons for this exclusion include the geographical isolation of these communities from decision-making centres in southern Canada, a lack of communication between management agencies and stakeholders, and a general lack of awareness among most Ontarians-including decision makers-of the existence of polar bears in Ontario. This ongoing failure is even more disconcerting when one considers the consultative obligations flowing from Treaty No. 9. We are aware that other Cree people in Manitoba and Quebec also have their own narrative to tell, and we encourage them to come forth and share their stories of Wabusk.

Media coverage regarding polar bear management in Canada has tended to simplify aboriginal concerns to a question of numbers; however, such conclusions are somewhat arbitrary and one-dimensional, for current polar bear management narratives extend beyond differences over harvest quota numbers or the impacts of climate change on polar bears. Indeed, these discussions highlight a colonial legacy in the Canadian North, and the inability or unwillingness of governments, both provincial and federal, to provide adequate funding for resource and wildlife management in Canada. Therefore, the present critique of polar bear management voiced by Inuit and their supporters should come as no surprise, for the only thing that has changed, according to Butler and Menzies (2007:16), is that "the cultural and political rights of indigenous peoples have been increasingly recognized both legally and in the public consciousness." Yet, despite having traditional rights to harvest polar bears, living and interacting with polar bears, and offering some polar bear viewing opportunities, the Muskekowuck Athinuwick/Cree People of northern Ontario have been largely marginalized in these debates and the legislative changes regarding polar bears proposed by various international, national, and provincial agencies. While the Ontario Ministry of Natural Resources does provide reports on the ongoing polar bear research in the region, these reports fail to address the complexities of polar bear management at a global scale.

The International Union for the Conservation of Nature (IUCN), the agency responsible for overseeing the agreement on polar bear conservation, has recently upgraded polar bears from "lower risk" (i.e., least concern) to "vulnerable." In Canada, polar bears are also listed as a species of "special concern" or "vulnerable" (Lunn et al., 2006). However, this status is subject to revision because of the 
new Species at Risk Act (SARA), which became law in Canada in 2002. Under SARA, a decision about adding the "polar bears to the List of Wildlife Species at Risk has been delayed pending further consultation" (Lunn et al., 2006: $15)$. One hypothesis is that the Canadian government is waiting to see the outcome of the proposed listing of polar bears on the U.S. Endangered Species Act in 2008. This "re-listing" of polar bears in the United States would increase the protection of these animals, especially of those populations co-managed by the United States and Canada, and bring the traditional polar bear harvest under greater scrutiny.

Such a decision would have profound impacts on Inuit communities who depend on tightly regulated conservation hunts of polar bears for additional income, and it could also affect the traditional harvest of polar bears in Canada by aboriginal people. While no conservation hunting by non-aboriginal people is permitted in Ontario, there is a small, tightly regulated aboriginal harvest of polar bears. The polar bear harvest by the Muskekowuck Athinuwick/ Cree People of northern Ontario has remained around 11 polar bear per years (Lemelin et al., in press). Some communities, for example, the Weenusk First Nation at Peawanuck, Fort Severn, also provide opportunities to view polar bears. While polar bear tourism generates millions of dollars in Canada and elsewhere, discussions regarding polar bear tourism have been largely relegated to debates over hunting quotas, while non-consumptive dimensions are rarely, if ever, mentioned. This is another shortcoming of the current discussions on polar bear management.

Further, the management of Wabusk has traditionally been largely dominated by a particular Western approach to wildlife management, with certain actors, stakeholders and indigenous groups consciously or unconsciously vying for control. For example, polar bear management has tended to emphasize either a conservationist utilitarian approach to game species management, or a preservationist approach that emphasizes the need to protect endangered species. These approaches tend to favour a grand narrative of resource management, in which wildlife is viewed as a resource, with experts as the arbiters of these interactions between humans and nature. Such a perspective, largely devoid of a socio-historical context, often lacks reflexivity, and can perceive alternative knowledge systems as a threat. The "counter-process" or "researchaffirmation by Inuit" is one of these alternative knowledge systems that also involves what Smith $(1999,2005)$ defined as a decolonization project involving "the unmasking and deconstruction of imperialism, and its aspect of colonialism, in its old and new formations alongside a search for sovereignty; for reclamation of knowledge, language, and culture; and for the social transformation of the colonial relations between natives and the experts" (Smith, 2005:89). If the management of polar bears is to be addressed in an appropriate and equitable fashion, then it will require the engagement of those northern communities who have lived with the polar bears for thousands of years, and who will be most influenced by these decisions. These include Inuit and Cree communities in northern Canada. Appropriate and equitable management will also require an approach to endangered species that goes beyond the affirmation that the legislation does not abrogate or derogate aboriginal and treaty rights to an approach that recognizes the jurisdiction of the Cree people in wildlife management.

In conclusion, traditional approaches to polar bear management, while effective in the past, may be somewhat limited given the present diversity of human interactions with polar bears. These humans include researchers, prospectors, aboriginal people, and tourists (both consumptive and non-consumptive). It thus behooves researchers to recognize the human dimensions of polar bear management. For if polar bear management is to address complex stressors and social changes and truly engage indigenous people with aboriginal and treaty rights, as well as other stakeholders, then a reflexive re-examination of the dominant wildlife management paradigm will be required. The acquiescence of some management agencies to co-management policies that include traditional ecological knowledge represents a small shift in this direction. However, true understanding of the interplay between social values and research will be possible only when indigenous people with aboriginal and treaty rights and their knowledge systems are recognized by all other stakeholders. Such discussions should occur sooner rather than later, given the actions proposed by the American and Canadian governments and the potential impact of climate change on polar bears.

\section{REFERENCES}

BUTLER, C., and MENZIES, C.R. 2007. Traditional ecological knowledge and indigenous tourism. In: Butler, R., and Hinch, $\mathrm{T}$., eds. Tourism and indigenous peoples: Issues and implications. New York: Elsevier. 15-27.

FREEMAN, M.M.R., and WENZEL, G.W. 2006. The nature and significance of polar bear conservation hunting in the Canadian Arctic. Arctic 59(1):21-30.

LATOUR, B. 1999. Pandora's hope: Essays on the reality of science studies. Cambridge, Massachusetts: Harvard University Press.

LEMELIN, R.H., McINTYRE, N., KOSTER, R., and JOHNSTON, M. In press. Polar bear management in Polar Bear Provincial Park and the Washeo and Weenusk First Nations. Conference Proceedings of Tourism and Global Change in Polar Regions: An International Conference, 29 November-1 December 2007, Oulu, Finland.

LUNN, N.J., BRANIGAN, M., CARPENTER, E.L., CHAULK, K., DOIDGE, B., GALIPEAU, J., HEDMAN, D., HUOT, M., MARAJ, R., OBBARD, M., OTTO, R., STIRLING, I., TAYLOR, M., and WOODLEY, S. 2006. Polar bear management in Canada 2001-2004. In: Aars, J., Lunn, N.J., and Derocher, 
A.E., eds. Polar bears: Proceedings of the 14th Working Meeting of the IUCN/SSC Polar Bear Specialist Group, 20-24 June 2005, Seattle, Washington, USA. Occasional Paper of the IUCN 32. Gland, Switzerland: Species Survival Commission. 117-132.

OBBARD, M.E., CATTET, M.R.L., MOODY, T., WALTON, L.R., POTTER, D., INGLIS, J., and CHENIER, C. 2006. Temporal trends in the body condition of southern Hudson Bay polar bears. Climate Change Research Information Note 3. Government of Ontario, Applied Research and Development Branch. 8 p. Available at http://assets.panda.org/downloads/ obbard_et_al_ccrn_3.pdf.

OBBARD, M.E., McDONALD, T.L., HOWE, E.J., REGEHR, E.V., and RICHARDSON, E.S. 2007. Polar bear population status in southern Hudson Bay, Canada. Reston, Virginia: U.S. Department of the Interior, U.S. Geological Survey.

SCOTT, D., MALCOLM, J.R., and LEMIEUX, C. 2002. Climate change and modelled biome representation in Canada's National park system: Implications for system planning and park mandates. Global Ecology and Biogeography 11:475-485.
SMITH, L.T. 1999. Decolonizing methodologies: Research and indigenous peoples. New York: St. Martin's Press.

. 2005. On tricky ground: Researching the native in the age of uncertainty. In: Denzin, N.K., and Lincoln, Y.S., eds. The Sage handbook of qualitative research, 3rd ed. Thousand Oaks, California: Sage Publications.

Harvey Lemelin is an associate professor in the School of Outdoor Recreation, Parks and Tourism at Lakehead University. He has been working with First Nations for the past 15 years. His most recent research is with the Weenusk First Nation at Peawanuck.

David Peerla earned a doctorate in sociology at the University of California, Santa Cruz. He is an advisor to the Nishnawbe Aski Nation.

Brian Walmark is the director of the Keeywaytinook Okimakanak Research Institute (KORI). His mother's people are members of Lac La Croix First Nation and his father's people are first-generation Canadians. 